\title{
《解 睍》
}

\section{ケミカル蓄熱技術 \\ Chemical Heat Storage}

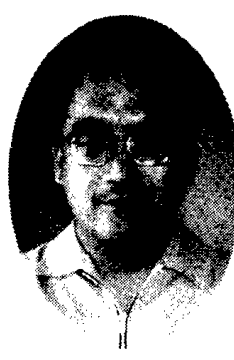

- 1947 年 6 月生まれ

1972 年早稲田大学大学院理工学研究科修士 課程修了. 同年東京工業試験所（現 工業技 術院物質工学工業技術研究所）入所，現在同 研究所主任研究官. ヒートポンプ技術, 蓄熱 技術ならびに結晶成長に関する研究に従事

正員, 工業技術院物質工学工業技術研究所 (テ305 つくば市東 1-1)

\section{1.はじめに}

ケミカル蓄熱技術は，熱エネルギーを化学エネ ルギーに変換して蓄熱する技術である．蓄熱に関 与する反応系の多くは，固気反応であり，その反 応熱や取扱いの容易さ等の観点から気相として水 蒸気，アンモニアあるいはメチルアミン等が関与 する反応系が用いられている(1)．また気相の圧力 条件を変化させることにより，放熱時の温度を蓄 熱時より上昇させて出力させる「ケミカルヒート ポンプ」としての応用も可能であり，今後の熱利 用技術として注目されている。

通商産業省のニューサンシャイン計画では， 1984 年から 1992 年の 9 年間にわたり「スーパヒ ートポンプ・エネルギー集積システム」(以下 SHP プロジェクト）の研究開発を行い，ケミカ ル蓄熱技術を開発してきた。ここでは，その成果 を中心としてケミカル蓄熱技術の概要について紹 介する.

\section{2. ケミカル蓄熱技術とは}

ケミカル蓄熱技術の作動原理を次式の水和反応 系（蓄熱媒体：臭化カルシウム水和塩）を例とし て図 1 に示す。

$$
\begin{aligned}
& \mathrm{CaBr}_{2} \cdot 2 \mathrm{H}_{2} \mathrm{O}(\mathrm{S}) \rightleftarrows \mathrm{CaBr}_{2} \cdot \mathrm{H}_{2} \mathrm{O}(\mathrm{S}) \\
& \quad+\mathrm{H}_{2} \mathrm{O}(\mathrm{g}) \\
& \mathrm{H}_{2} \mathrm{O}(\mathrm{g}) \rightleftarrows \mathrm{H}_{2} \mathrm{O}(\ell)
\end{aligned}
$$

$\mathrm{S}$ : 固相, $\mathrm{g}$ : 水蒸気または気相, $\ell$ : 液相

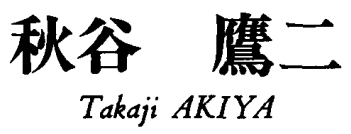

蓄熱時には， $150^{\circ} \mathrm{C}$ の熱源により，式(1)の熱 分解反応（右向き）を行わせる。発生する蒸気 は， $25^{\circ} \mathrm{C}$ の冷却水により凝縮させ，蓄熱槽内の 圧力を飽和蒸気圧以下に保ち, 熱分解反応が円滑 に進むようにする．放熱時にはこの凝縮水を補助 熱源（ここでは $70^{\circ} \mathrm{C}$ ) により蒸発させ，上記の 逆反応（左向き）を進めその際の反応熱を利用す る.また,図 1 の操作線図から補助熱源の温度を変 化させることにより, 発生する蒸気の圧力をコン トロールし，臭化カルシウムの水和反応の反応温 度を補助熱源の温度により決めることが可能とな る.このようにしてケミカル蓄熱技術では, 反応条 件をコントロールすることによりケミカルヒート ポンプサイクル構成することを可能としている.

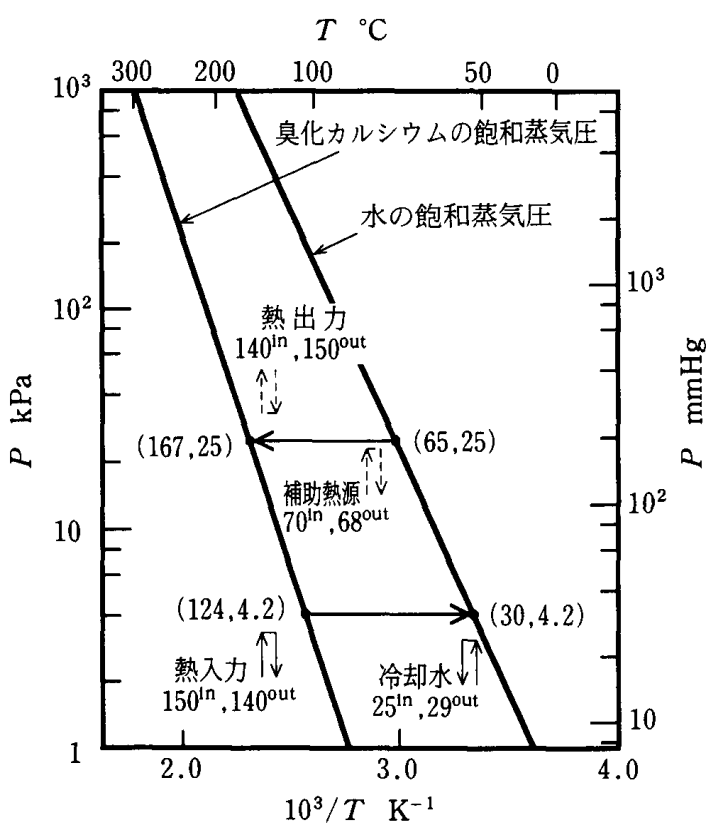

図 1 臭化カルシウムの操作線図 
表 1 SHP プロジェクトで開発された 高温ケミカル蓄熱技術

\begin{tabular}{c|c|c}
\hline \hline $\begin{array}{c}\text { 反応に関与 } \\
\text { する適用温度 }\end{array}$ & 反 応 系 \\
\hline アンモニア & $200^{\circ} \mathrm{C}$ & $\begin{array}{c}\mathrm{NiCl}_{2} \cdot 6 \mathrm{NH}_{3} / 2 \mathrm{NH}_{3} \\
\mathrm{NaSCN} \cdot 3.7 \mathrm{NH}_{3} / 4.7 \mathrm{NH}_{3}\end{array}$ \\
\hline 水蒸気 & $150^{\circ} \mathrm{C}$ & $\mathrm{CaBr}_{2} \cdot 2 \mathrm{H}_{2} \mathrm{O} / \mathrm{H}_{2} \mathrm{O}$ \\
\hline $\mathrm{TFE}$ & $85^{\circ} \mathrm{C}$ & $\mathrm{E} 181 / \mathrm{TFE}$ \\
\hline
\end{tabular}

(E 181：テトラエチレングリコールジメチルエーテル, $\mathrm{TFE}$ ：トリフルオロエタノール)

\section{3. ケミカル蓄熱装置に係わる 熱工学的課題}

ケミカル蓄熱では，既に説明したように固気反 応を用いる場合が多く，反応系の選択など化学的 な課題と共に熱工学的にも課題が多い.

蓄熱装置は固気反応を用いることから必然的に 充てん層形固相反応器を中心とすることになる. 従って，蓄熱時には反応（蓄熱）媒体である充て ん層粒子の熱分解反応をいかに効率的に進めるか ということが重要となる，反応条件を考えてみる と充てん層内は減圧条件下にあり，また，充てん 粒子は反応前後の体積変化を考慮して比較的疎に 充てんしてある。熱工学的観点から課題を整理す ると，

（1）減圧条件から対流伝熱が困難

(2) 温度が低いことから輻射伝熱が期待できない

（3）充てん粒子の空間率も，最密充てんに比べ 小さいことから伝導伝熱も困難

（4）その他

などの問題が見いだされる。これらの問題を解 決するために装置的にはプレートフィン形の熱交 換器を模したタイプの反応装置を工夫し，伝熱媒 体との効率的な伝熱操作を図っている。このこと は, 従来の反応の解析という観点に加え, 今後は 熱機器としての実用機の概念を踏まえた熱工学的 な研究がより重要になることを意味している。

SHP プロジェクトでは, 表 1 に示す気相とし て水蒸気，アンモニアおよび TFEが関与する蓄 熱技術が研究された.いずれの反応系についても

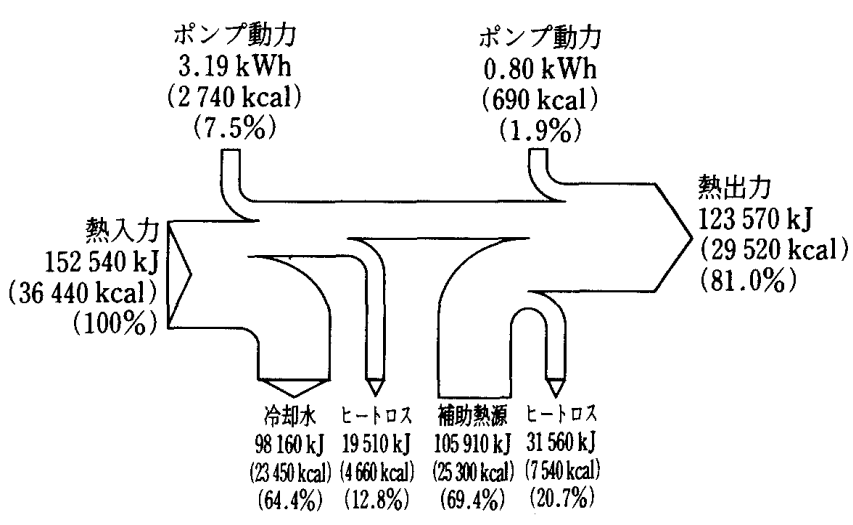

図 2 エネルギーフローチャート

実用機規模の蓄熱容量を持つ装置において, 熱回 収率 $75 \%$ および蓄熱密度 $209 \mathrm{~kJ} / \mathrm{kg}$ が達成でき ることが明らかにされた(2).

図 2 に蓄熱量 $115 \mathrm{MJ}$ の蓄熱装置による水和反 応系の蓄熱/放熱サイクルにおける熱収支を示し た。蓄熱/放熱運転は蓄熱 10 時間, 放熱 7.5 時 間，切り替えおよび待機時間 6 時間とした 24 時 間サイクルで運転したものである。図 2 から，蓄 熱時においては熱入力の大部分が冷却水の形で外 部に捨てられ，また放熱時においては補助熱源と して持ち込まれた熱が最終的に出力されているこ とが読み取れる。このことから，ケミカル蓄熱技 術の実用化に当たっては，この補助熱源に注目 し，ケミカルヒートポンプへの応用も重要である ということが明らかとなった。

\section{4.おわりに}

ケミカル蓄熱技術について SHP プロジェクト の成果を中心として説明した，環境・省エネルギ 一問題を考えればヒートポンプへの展開が可能で あるケミカル蓄熱技術は重要である，小文が参考 になれば幸いである。

\section{文献}

（1）藤原・ほか, 化学工業資料, 18 (1983), 12.

（2）新エネルギー・産業技術総合開発機構編，スーパーヒート ポンプエネルギー集積システム 8 年間の研究開発の成 果, (1993), 26.

(原稿受付 1994 年 6 月 15 日) 